\title{
Natural Cytotoxicity Triggering Receptor 2
}

National Cancer Institute

\section{Source}

National Cancer Institute. Natural Cytotoxicity Triggering Receptor 2. NCI Thesaurus.

Code C104546.

Natural cytotoxicity triggering receptor $2(276 \mathrm{aa}, \sim 30 \mathrm{kDa}$ ) is encoded by the human NCR2 gene. This protein is involved in natural killer cell function. 